\title{
Mobile Banking Adoption: An Exploration of The Behavioural Intention of Consumers in Ireland
}

\author{
Philip McGovern \\ National College of Ireland \\ Jonathan Lambert \\ National College of Ireland \\ Michael Verrecchia \\ Management Consultant
}

This paper investigates mobile banking adoption in Ireland and identifies constructs that influence consumers' behavioural intentions to adopt mobile banking. A survey tested relationships between proposed factors and consumers' behavioural intentions. Findings indicate perceived trust, perceived usefulness and compatibility are important influencing factors on consumers' behaviour. The paper concentrates on six factors affecting behavioural intention to adopt mobile banking. There is a high probability that consumers adopt mobile banking if it is compatible with beliefs, values and, lifestyle experiences. Few studies addressed mobile banking applications on mobile devices in developed nations, nor explored reasons for/against mobile banking adoption in Ireland.

Keywords: Mobile Banking, Behavioural Intention, Technology Adoption

\section{INTRODUCTION}

Mobile banking is one of the latest technological advances that financial institutions are attempting to leverage as a distribution channel (Nel \& Boshoff, 2014; Walid \& Kamel, 2019). The integration of internet technologies and mobile networks has created new opportunities for delivery of banking services. Mobile banking provides a ubiquitous delivery mechanism for banking services due to increased usage of smart mobile phones and tablet personal computers (PCs) (Dash \& Bhusan, 2014; Wafi, 2016). As a result of mobile devices overtaking desktop PC's, mobile banking has increased in importance as a potential service delivery channel (Wafi, 2016). The delivery of mobile banking services is expected to significantly change the banking business model (Moser, 2014; Shaikh \& Karjaluoto, 2015; Backbase, 2017; PwC, 2018).

The literature makes constant reference to the need to examine factors influencing the adoption and use of mobile banking (Koksal, 2016; Walid \& Kamel, 2019). Existing research predominately focused on Short Message Service (SMS) banking in developing nations. Additionally, there are few studies that 
directly address the adoption and use of mobile banking via mobile banking applications on smartphones or tablet PCs in developed nations (Shaikh \& Karjaluoto, 2015; Wafi, 2016).

The aim of this study is to (a) fill the identified research gap in the context of Ireland (b) review existing literature on mobile banking adoption (c) develop a conceptual model to identify the most important factors influencing consumers' behavioural intentions to adopt mobile banking in Ireland.

\section{LITERATURE REVIEW}

Mobile banking is a variant of electronic banking that offers similar services and benefits to consumers as internet banking. Mobile banking represents enhanced "anywhere anytime" banking services over other banking channels. The benefits of mobile banking include: Immediacy, Location, Convenience, Customisation, Identifiability, Ubiquity and Functionality (Ha et al., 2012; Malaquias \& Hwang, 2016; Shamsul et al., 2017). Mobile banking and internet banking share many common services, functions and benefits. However, there are perceived differences between customer value propositions of both services (Laukkanen, 2007; Backbase, 2017; PWC, 2018. Internet banking is considered to be the preferred channel for account access and basic banking transactions (Nel \& Boshoff, 2014). The expected growth in mobile banking usage has not materialised over the past decade (Yu, \& Chantatub, 2016: Wafi, 2016). This may be attributed to the view that mobile banking is not perceived as a trusted channel for banking transactions (Nel \& Boshoff, 2014; Ernst \& Young, 2017).

Three of the four methods by which consumers access mobile banking services require an internet connection while the fourth method relies on a Global System for Mobile Communication (GSM): firstly, mobile applications downloaded to a smartphone, secondly, to a tablet PC, thirdly, to a web browser on mobile or smartphones and finally, short messaging services (SMS) (Wafi, 2016). Banking Payments Federation Ireland (BPFI) (2018), considers online banking and mobile banking as separate activities, excluding web browsers used on mobile or smartphones.

Ernest and Young's (2017) global consumer banking survey found that $41 \%$ of Irish consumers were using online banking, while just under $32 \%$ use mobile banking. However, its growth rate relative to other mobile services such as instant messaging and micro blogging means that mobile banking may be considered a slow-diffusion innovation (Garcia et al. 2007; Shaikh \& Karjaluoto, 2015; Yu \& Chantatub, 2016).

In the context of service delivery and value creation, mobile banking has fundamentally changed the nature of financial services (Bitner et al., 2000). It has also led to a significant shift from a traditional interpersonal-based relationship to a technology-based interaction (Yang \& Park, 2011). According to Vargo and Lusch, (2008), the purpose of this interaction is to facilitate value co-creation. Using service technology, banks provide mobile banking as a platform to interact with their customers for the purpose of value creation (Vargo \& Lusch, 2008; Muñiz \& Schau, 2011).

Previous research on mobile banking adoption provided valuable clues in formulating strategies in banking technology innovation (Yu \& Chantatub 2016). Factors affecting consumer participation in innovations, such as perceived usefulness, perceived ease-of use, and relative advantages were investigated (Gurtner et al., 2014). However, not every technology innovation, which may be beneficial to customers is quickly accepted. Previous studies confirm that $40 \%-90 \%$ of innovations fail (Gourville 2006). Even though banks are aware of those adoption cues, customer participation in mobile banking has grown lower than expected (Shaikh \& Karjaluoto 2015; Yu \& Chantatub 2016).

There is increasing demand by consumers for convenience (growth in account logins) and there is potential for mobile banking applications as a distribution channel for banking services (increased levels of customer interaction with banking services (PwC, 2018; Walid \& Kamel, 2019). However, encouraging consumers to participate in mobile banking for value creation is not an easy task - they must first overcome initial resistance (Kuisma et al., 2007). Adoption and resistance can also coexist (Yu \& Chantatub 2016). In other words, customer resistance and adoption are two sides of the coin to determine the successful commercialisation of mobile banking. Although the importance of customer resistance to innovation is recognised in research, resistance to innovation has received insufficient attention (Garcia et 
al., 2007; Laukkanen \& Kiviniemi, 2010; Heidenreich \& Handrich, 2015). There is limited research on customer adoption behaviour from a resistance perspective (Laukkanen \& Kiviniemi, 2010; Laukkanen, 2016; Yu \& Chantatub, 2016). This highlights the need for further investigation into mobile banking adoption to ascertain key factors influencing adoption and continued use for consumers and organisations.

The literature found that adoption should focus on the benefits of mobile banking; its usefulness and compatibility with users' lifestyles, while also emphasising risk minimisation (Lee et al., 2013; Dash \& Bhusan, 2014; Ramlugun \& Issuree, 2014; Shaikh \& Karjaluoto, 2015; Yu et al. 2015; Alalwan et al., 2016; Wafi, 2016). One of the most important factors influencing mobile banking adoption has been consumer trust (Talukder et al. 2014; Koksal, 2016).

\section{CONCEPTUAL FRAMEWORK}

The two predominant models utilised to study mobile banking acceptance are the Technology Acceptance Model (TAM) (Davis, 1989) and the Innovation Diffusion Theory (IDT) (Rodgers, 2003). TAM focuses on underlying characteristics of the technology, its perceived usefulness and perceived ease of use. IDT focuses on the five characteristics of innovation diffusion: relative advantage, complexity, compatibility, trialability and observability which are relevant factors associated with innovation adoption or mobile banking adoption (Agarwal \& Prasad, 1998; Rodgers, 2003; Shaikh \& Karjaluoto, 2015).

\section{Technology Acceptance Model (TAM)}

TAM is a model that has benefited from validation in several empirical studies (Cheung \& Chang, 2001; Raida \& Neji, 2013). It was developed by Davis in 1989 and explains the behaviour of information technology adoption (Phuangthon \& Malisawan, 2005). It is based on the fact that adoption is contingent on the influence of the perceived ease and the perceived usefulness of the user (Raida \& Neji, 2013).

According to TAM, the actual use of a technology is determined by beliefs a user holds about its perceived usefulness and its perceived ease of use. Perceived usefulness refers to the extent to which people believe that a technology will help them perform a task better, while perceived ease of use refers to the degree to which a person believes that using a particular technology would be free of effort (Illia et al., 2015).

TAM is the most common research model utilised in mobile banking. It has been tested, validated and can be easily adapted using other theoretical constructs (Venkatesh \& Davis, 2000; Ramlugun \& Issuree, 2014; Shaikh \& Karjaluoto, 2015). TAM asserts that perceived usefulness (PU) and perceived ease of use (PEOU) are the most significant factors in technology acceptance behaviour and as such are the best indicators of current usage and predicted future usage (Davis, 1989). Individuals either adopt or reject applications based on their ability to perform a task, the greater the PU of a new technology the greater the probability it will be adopted (Davis, 1989). Users either adopt or reject the application based on their perceptions of how difficult it is to use (PEOU). Perceived trust and self-efficacy are also important drivers of mobile banking adoption (Shaikh \& Karjaluoto, 2015).

The conceptual framework draws primarily on TAM while integrating factors from IDT. As TAM excludes economic, demographic and other external factors it is seen as limited in its ability to explain users' intentions and attitudes towards mobile services adoption (Venkatesh \& Davis, 2000). To allow for this shortcoming many studies on mobile banking adoption have extended TAM to include the constructs of relative advantage and compatibility from IDT (Shaikh \& Karjaluoto, 2015).

\section{Innovation Diffusion Theory (IDT)}

Innovation Diffusion Theory (IDT) is the second most popular research model used to investigate mobile banking adoption. Shaikh \& Karjaluoto, (2015) found that $16 \%$ of studies used IDT as its theoretical research framework while TAM accounted $42 \%$ of studies. IDT has been used to identify factors that act as facilitators and inhibitors of mobile banking adoption and use (Al-Jabri \& Sohail, 2012; Dash \& Bhusan, 2014). 
Salahuddin et al., (2017) argue that individuals' perceptions toward the attributes of an innovation enhance the rate of adoption. According to IDT, people obtain, organise information and form perceptions about that specific innovation and based on these perceptions, decide whether to accept or reject the innovation (Rogers, 2003).

IDT explains how over time a new idea, innovative new product or process is adopted and filters across a population or society. Within the context of IDT adoption is considered to take place when an individual does something in a different way than previously, and for adoption to have taken place, the individual must perceive the idea, behaviour or product as new or innovative (Rodgers, 2003).

\section{TAM and IDT}

This research paper utilised a theoretical framework that blends the Technology Acceptance Model (TAM) with Innovation Diffusion Theory (IDT) to develop a research framework composed of six innovation attributes (perceived usefulness, perceived ease of use, compatibility, perceived risk/credibility, self-efficacy, perceived trust) expected to influence consumer intention towards mobile banking adoption. Perceived usefulness (PU), perceived ease of use (PEOU) and compatibility are seen to be significant factors in the literature, while self-efficacy and perceived trust have a positive but less significant impact on adoption intentions, and perceived risk is considered to have a negative impact. Trialability and observability are excluded from the framework as research indicates there is little correlation between IT adoption and these constructs (Tung et al., 2014).

The identified framework variables include:

- Technology characteristics of perceived usefulness (PU) and perceived ease of use (PEOU)

- Innovation attribute of compatibility with lifestyle, experiences, values and beliefs

- Barriers to adoption including perceived risk and perceived trust

- Technological readiness of adopters is measured by self-efficacy, the consumer's ability to use the technology

\section{RESEARCH QUESTIONS}

This research paper concentrated on testing six hypotheses, namely:

H1: Perceived usefulness will have a positive impact on behavioural intention to use mobile banking mobile banking;

H2: Perceived ease of use increases the behavioural intention of individuals to adopt mobile banking;

H3: Perceived risk will have a negative effect on behavioural intention to adopt mobile banking;

H4: Compatibility will have a positive effect on behavioural intention to adopt mobile banking;

H5: Trust will have a positive effect on behavioural intention to adopt mobile banking;

H6: Self-efficacy will have a positive effect on behavioural intention to adopt mobile banking.

\section{RESEARCH METHODOLOGY}

\section{Research Design}

This study considers a cross-sectional view of mobile banking adoption in Ireland attempting to identify the constructs that significantly influence consumers' behavioural intentions to adopt mobile banking. A self-administrated questionnaire was designed and administrated following a snowball sample methodology. The survey was subdivided into three parts: 
- Demographic characteristics covering participant age, gender, highest level of education and mobile banking experience;

- Conceptual framework constructs which included the two TAM constructs perceived usefulness and perceived ease of use; in addition to the four IDT constructs compatibility, perceived risk, perceived trust and self-efficacy;

- Behavioural intention construct;

- Independent and dependent variable constructs were measured on 7-point Likert scales designed to examine respondents' behaviour related to the conceptual framework constructs and ranged across possible responses of "strongly disagree," "undecided," and finally "strongly agree". A covering email invitation explained the rationale for the study and included the researchers' contact information.

\section{Sample}

The sample consisted of 244 participants selected using a snowball sampling methodology. Of the 244 participants $135(55 \%)$ were male, with the remaining $109(45 \%)$ female. The age profile of the sample ranged from a minimum age category of 20 to 29 years to participants aged greater than 65 years. In particular, 20 to 29 -year-old participants represented $16 \%$ of the sample, 30 to 39 -year-old participants represented $31 \%$ of the sample, with 40 to 49 -year-old participants representing 32\%, 50 to 59-year-old participants represented $16 \%$, and those aged older than 59 years $(60+$ years $)$ accounted for approximately $5 \%$ of the sample group. Education levels, in particular, highest education classifications, ranged from Leaving Certificate through to Ph.D. holders. In particular, those indicating that their highest level of education was a Leaving Certificate accounted for $10 \%$ of the overall sample, Higher Diploma holders represented $14 \%$, undergraduate degree holders represented $41 \%$, those with a master's level qualification represented $34 \%$, with approximately $5 \%$ of the sample holding a Ph.D.

\section{Measures}

Dependent Variable

Theory of Reasoned Action (TRA) (Tung et al., 2014) endeavours to understand the voluntary behaviour of individuals and what motivates their actions. It contends that intention precedes action and that this behavioural intention is the result of expectations that the behaviour will result is a specific outcome. TRA argues that behavioural intention is a measure of the strength of intention to perform a behaviour, as such the greater the behavioural intention the greater the effort to perform a specific behaviour for an individual which in turn increases the chances of a behaviour's performance. The dependent variable behavioural intention, adapted from Gu et al., (2009), Lee, (2009) and Luarn \& Lin, (2005) consisted of a four item response inventory, canvasing responses on the four items "I intend to use mobile banking regularly in the future," "I will use mobile banking for my banking needs," "I intend to use mobile banking more regularly in the future," "I will frequently use mobile banking in the future". Each item being measured on the previously detailed 7-point Likert scales. Overall respondent behavioural intention was developed as an equally weighted summation of responses on the four-item inventory. The responses ranged from 4, indicating low behavioural intention, through to 28, indicating a level of high behavioural intention to use mobile banking technology. Cronbach's alpha for the four-item inventory was 0.958 .

\section{Independent Variables}

The Technological Acceptance Model (TAM) defines perceived usefulness and perceived ease of use as measures of the degree to which a participant believes that technological use will enhance their day-today banking and would not involve extra effort to achieve their goal above and beyond what they use to date. Both constructs were measured using four item inventories (Table 1). Internal scale consistency was measured using Cronbach's alpha, perceived usefulness having an alpha value of 0.938 , with the perceived ease of use subscale having an alpha value of 0.918 . 


\section{TABLE 1 \\ TECHNOLOGY ACCEPTANCE MODEL CONSTRUCTS OF PERCEIVED USEFULNESS AND PERCEIVED EASE OF USE}

\begin{tabular}{lll}
\hline Perceived Usefulness & Perceived Ease of Use \\
\hline $\begin{array}{l}\text { Using mobile banking enables me to do } \\
\text { my banking transactions quicker; }\end{array}$ & - Mobile banking is easy to use; \\
- Using mobile banking makes it easier to & - Learning to use mobile banking is easy; \\
do my banking transactions; & $\begin{array}{l}\text { a lot of mental effort; } \\
\text { - Using mobile banking enhances the } \\
\text { efficiency of my banking activities; }\end{array}$ & $\begin{array}{l}\text { It is easy to become skilful in using } \\
\text { mobile banking; }\end{array}$ \\
Mobile banking is useful; & \\
\hline
\end{tabular}

Table 2 lists the four constructs associated with the Innovation Diffusion Theory scale and the fiveitem compatibility subscale, the four-item perceived trust subscale, the four-item perceived risk subscale, and the four item self-efficacy subscale. All items composing the respective subscales being measured on 7-point Likert scales. Overall subscale respondent belief was developed as an equally weighted summation of responses across all items composing the subscales inventory. With the exception of the five-item compatibility subscale, theoretical responses ranged from 4, indicating low belief in the construct, through to 28 , indicating a level of high agreement in the construct being measured. With respect to the five-item compatibility subscale, theoretical reposes ranged between 4 and 35 . All scales were deemed reliable with respective Cronbach alpha measures of 0.840 (compatibility), 0.936 (perceived trust), 0.979 (perceived risk) and 0.917 on the self-efficacy subscale.

\section{Analytic Approach}

A hierarchical multiple linear regression analysis was undertaken to predict behavioural intention based on the six constructs that compose the Technological Acceptance Model and the Innovation Diffusion Theory, namely: perceived ease of use, perceived usefulness, compatibility, perceived risk, perceived trust and respondent's self-efficacy; controlling for the variance attributable to gender, age and highest level of education. In addition, a bootstrap simulation was undertaken with 1000 iterations. The bootstrap was based on a stratified random sampling strategy with the demographic variables gender, age and highest level of education defining the strata. 
TABLE 2

INNOVATION DIFFUSION THEORY CONSTRUCTS COMPATIBILITY, PERCEIVED TRUST, PERCEIVED RISK, AND SELF-EFFICACY

\begin{tabular}{ll} 
Compatibility & Perceived Trust \\
\hline
\end{tabular}

- Mobile Banking fits well with the way I like to manage my finances

- I like to try new technology

- I like to adopt new innovation Mobile

- Banking is compatible with my lifestyle

- Using Mobile Banking fits into my working style
- Mobile Banking is trustworthy

- Mobile Banking keeps its promises and commitments

- Mobile Banking serves the present and future interests of users

- Overall, I trust Mobile Banking
Perceived Risk

- Considering the possibility of monetary loss associated with Mobile Banking, how risky do you consider mobile banking to be?

- Considering the possibility of harm to you resulting from the misuse of important personal and financial information due to the use of Mobile Banking, how risky do you consider mobile banking to be?

- Considering the possible loss of privacy because of information collected about you as you use mobile banking, how risky do you consider mobile banking to be?

- How risky do you rate Mobile Banking?

\section{Self-Efficacy}

- I am confident of using Mobile Banking even if there is no one around to show me how to do it

- I am confident of using Mobile Banking even if I have only the online instructions for reference

- I am confident of using Mobile Banking even if I have just the online "help" function for assistance

- I am confident in using Mobile Banking if I have sufficient time to complete the transactions

\section{FINDINGS}

An analysis of the differences in behavioural intention of sample participants was undertaken across all demographic variables. In the case of gender, distributional characteristics of both male and female behavioural intentions are presented in figures 1 and 2. Due to deviations in normality of the male distribution $(\mathrm{W}=.69, \mathrm{df}=129, \mathrm{p}<.001)$ and the female distribution $(\mathrm{W}=.71, \mathrm{df}=104, \mathrm{p}<.001)$ the nonparametric Mann-Whitney $U$ test was undertaken to ascertain if median behavioural intention scores were different for males compared to females. The results indicating no statistically significant difference between the median behavioural intention scores of males $\left(M_{d}=26.0\right)$ compared to females $\left(M_{d}=24.0\right)$ $(\mathrm{U}=6262.5, \mathrm{p}=.35)$. 
FIGURE 1

MALE AND FEMALE BEHAVIOURAL INTENTION DISTRIBUTIONS DETAILING SIGNIFICANT NEGATIVE SKEWNESS.

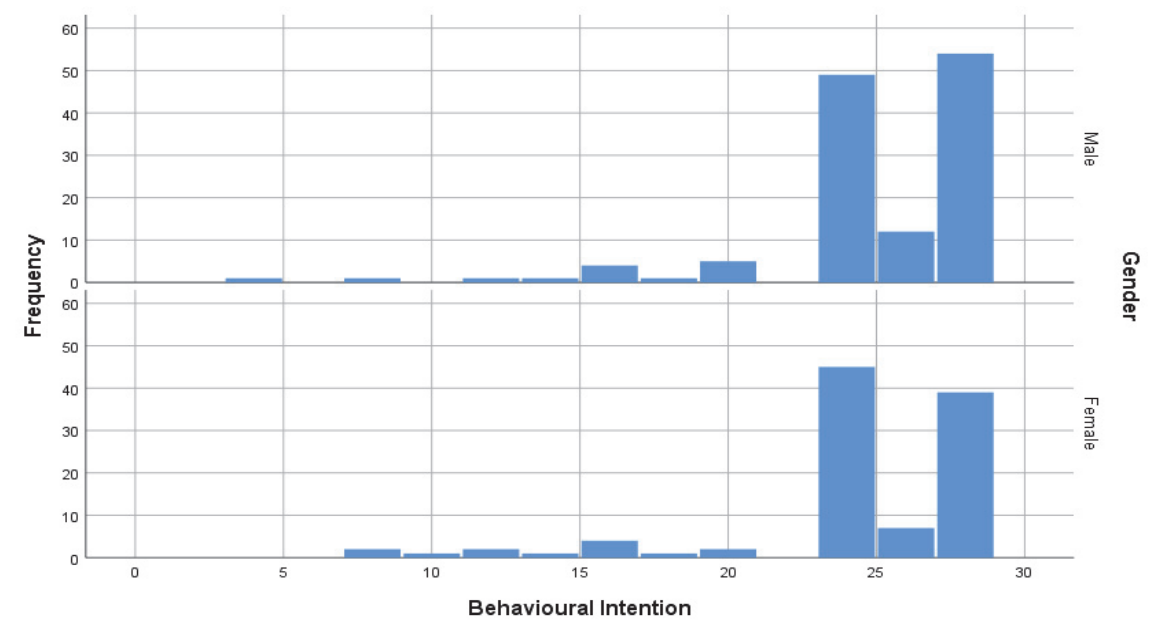

FIGURE 2

MALE AND FEMALE BEHAVIOURAL INTENTION DISTRIBUTION DETAILING QUARTILE LEVEL STATISTICS

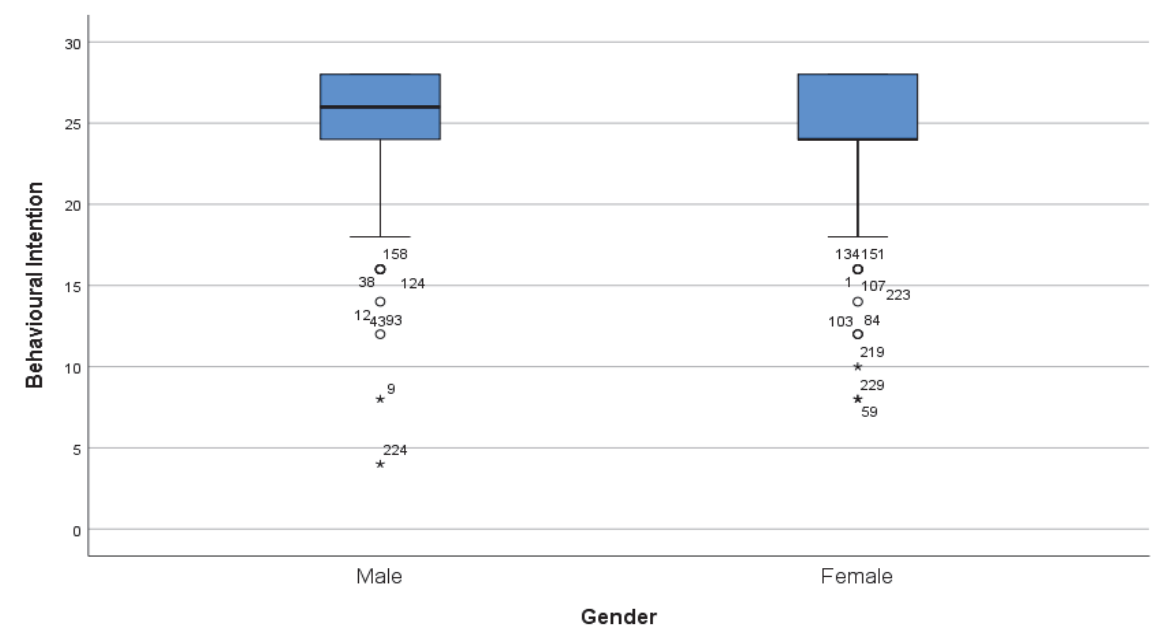

An analysis of the differences in behavioural intention based on sample participant age was undertaken. Assessments of distributional shape indicating statistically significant deviations from normality on behavioural intention at all age category levels (Table 3 and Figure 3). As such, the nonparametric Kruskal-Wallis $\mathrm{H}$ test was undertaken to ascertain if median behavioural intention scores were different between age categories. The results indicating statistically significant differences in median behavioural intention scores between age categories $(\mathrm{H}=11.05, \mathrm{df}=4, \mathrm{p}=.026)$. 
TABLE 3

NORMALITY RESULTS ON BEHAVIOURAL INTENTION ACROSS AGE CATEGORIES

\begin{tabular}{|c|c|c|c|}
\hline Age & $\mathbf{W}$ & df & $\mathbf{P}$ \\
\hline $20-29$ & 0.653 & 35 & 0.000 \\
\hline $30-39$ & 0.706 & 73 & 0.000 \\
\hline $40-49$ & 0.666 & 78 & 0.000 \\
\hline $50-59$ & 0.674 & 36 & 0.000 \\
\hline $\begin{array}{ll}60 & \text { or } \\
\text { older } & \end{array}$ & 0.826 & 11 & 0.021 \\
\hline
\end{tabular}

FIGURE 3

BEHAVIOURAL INTENTION DISTRIBUTIONS DETAILING QUARTILE LEVEL STATISTICS ACROSS AGE CATEGORIES

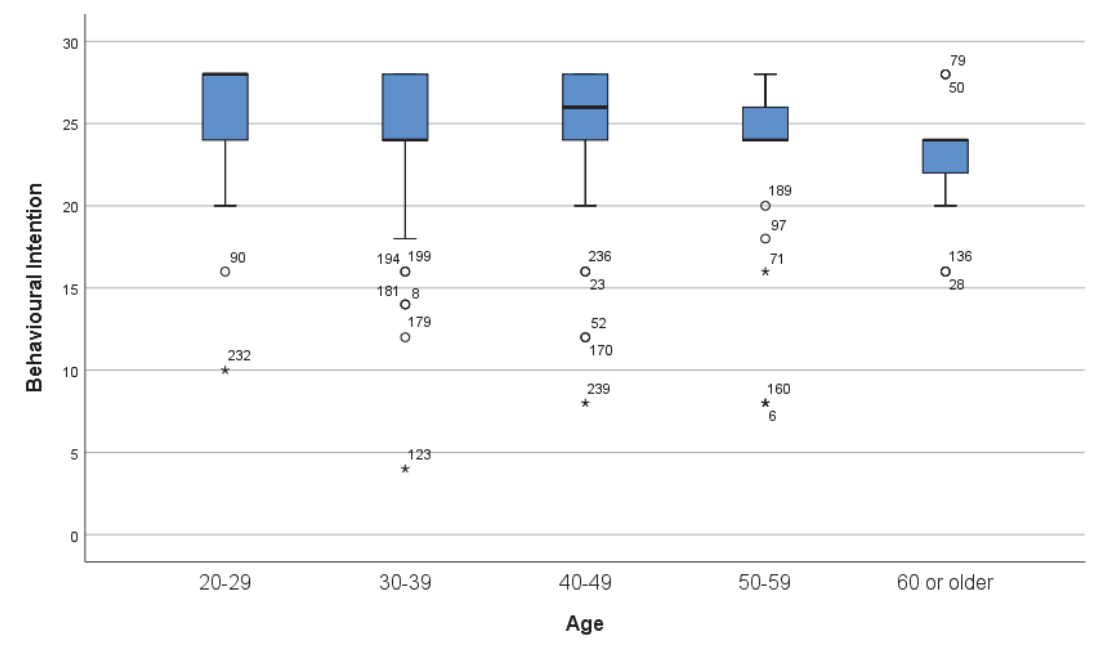

Follow up post-hoc tests indicating statistically significant differences between 20-29-year olds and both age categories covering the 50+ age groups. Similar differences being observed for the $40-49$ age category when compared to the two 50+ age groups. The results are presented in Table 4.

TABLE 4

RESULTS OF POST-HOC TESTS OF DIFFERENCE ON MEDIAN BEHAVIOURAL INTENTION SCORES BETWEEN AGE CATEGORIES

\begin{tabular}{llllll}
$\begin{array}{l}\text { Age } \\
\text { Category }\end{array}$ & $\mathbf{M}_{\mathbf{d}}$ & $\begin{array}{l}\text { Age } \\
\text { Category }\end{array}$ & $\mathbf{M}_{\mathbf{d}}$ & $\mathbf{U}$ & $\mathbf{P}$ \\
\hline $20-29$ & 28.0 & $50-59$ & 24.0 & 436.5 & 0.016 \\
$20-29$ & 28.0 & $60+$ & 24.0 & 110.5 & 0.033 \\
$40-49$ & 26.0 & $50-59$ & 24.0 & 1043 & 0.019 \\
$40-49$ & 26.0 & $60+$ & 24.0 & 260.5 & 0.025 \\
\hline
\end{tabular}

Behavioural intention across education levels indicated statistically significant differences between sample participant mean rank score $(H=12.01$, $\mathrm{df}=4, \mathrm{p}=.017)$. A follow-up post hoc analysis 
indicating differences between those that had a Leaving Certificate $(M=40.74)$ compared to those that held an undergraduate degree $(\mathrm{M}=62.99),(\mathrm{U}=624.5, \mathrm{p}=.003)$; as well as between Leaving Certificate $(\mathrm{M}=40.14)$ and those that hold a master's level degree $(\mathrm{M}=53.85),(\mathrm{U}=612.0, \mathrm{p}=.042)$.

\section{Predictors of Behavioural Intention}

Table 5 provides an overview of the usual descriptive statistics for the dependent variable behavioural intention and the two TAM constructs perceived ease of use, and perceived usefulness; in addition to the four IDT constructs. For example, average behavioural intention construct scores are reported as 24.72, with an associated median score of 24.00. The behavioural intention distribution is negatively skewed $\left(\mathrm{S}_{\mathrm{k}}\right.$ $=-2.20)$ with excess kurtosis $(\mathrm{K}=5.81)$. Observations on the scale range from the minimum achievable score of 4.00 through to the maximum score of 28.00. All construct distributions are negatively skewed.

TABLE 5

\section{DESCRIPTIVE STATISTICS FOR BEHAVIOURAL INTENTION AND THE TWO TAM ALONG WITH THE FOUR IDT CONSTRUCTS}

\begin{tabular}{|c|c|c|c|c|c|c|c|c|c|}
\hline & $\mathbf{M}$ & $\mathbf{M}_{\mathbf{d}}$ & SD & $\mathbf{S}_{\mathrm{k}}$ & $\mathbf{K}$ & Min & $\operatorname{Max}$ & Q1 & Q3 \\
\hline $\begin{array}{l}\text { Behavioural } \\
\text { Intention }\end{array}$ & 24.72 & 24.00 & 4.22 & -2.20 & 5.81 & 4.00 & 28.00 & 24.00 & 28.00 \\
\hline Perceived Ease Of & & & & & & & & & \\
\hline & 24.33 & 24.00 & 3.46 & -2.34 & 8.79 & 4.00 & 28.00 & 24.00 & 26.00 \\
\hline $\begin{array}{l}\text { Perceived } \\
\text { Usefulness }\end{array}$ & 25.30 & 27.00 & 3.86 & -2.36 & 7.18 & 4.00 & 28.00 & 24.00 & 28.00 \\
\hline Compatibility & 29.34 & 30.00 & 4.73 & -1.27 & 2.08 & 11.00 & 35.00 & 27.00 & 33.00 \\
\hline Perceived Risk & 19.36 & 21.00 & 5.90 & -0.80 & -0.32 & 4.00 & 28.00 & 15.00 & 24.00 \\
\hline Perceived Trust & 22.44 & 24.00 & 4.06 & -1.89 & 3.68 & 6.00 & 28.00 & 22.00 & 24.00 \\
\hline Self-efficacy & 23.91 & 24.00 & 4.15 & -1.91 & 4.41 & 7.00 & 28.00 & 24.00 & 28.00 \\
\hline
\end{tabular}

The degree of linear relationship was assessed through the visual inspection of scatterplots for behavioural attention against each of the six independent variables. These relationships are presented in Figures 4 through to 9 . The scatterplot of the relationship between behavioural intention and perceived risk showing a slight degree of non-linearity (Figure 7). Similarly, the scatterplot of the relationship between behavioural intention and self-efficacy showing a slight degree of non-linearity (Figure 9).

\section{FIGURE 4 \\ SCATTERPLOT OF THE RELATIONSHIP BETWEEN BEHAVIOURAL INTENTION AND PERCEIVED EASE OF USE}

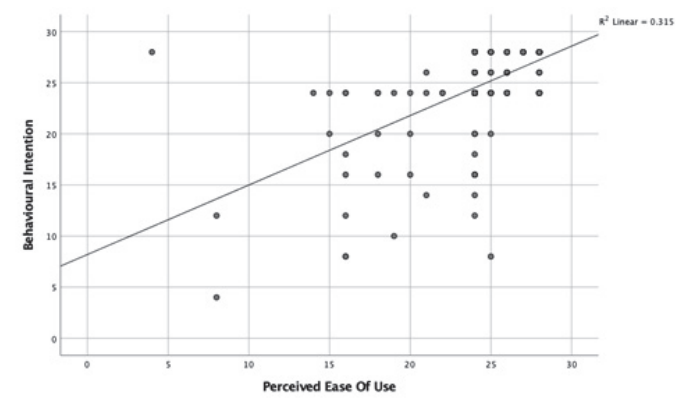


FIGURE 5

SCATTERPLOT OF THE RELATIONSHIP BETWEEN BEHAVIOURAL INTENTION AND PERCEIVED USEFULNESS

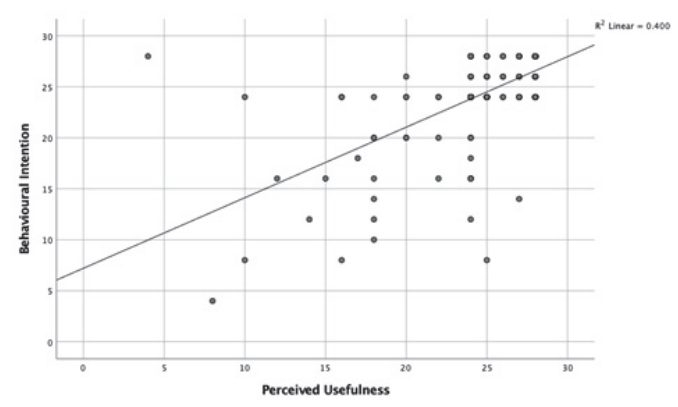

FIGURE 6

SCATTERPLOT OF THE RELATIONSHIP BETWEEN BEHAVIOURAL INTENTION AND COMPATIBILITY

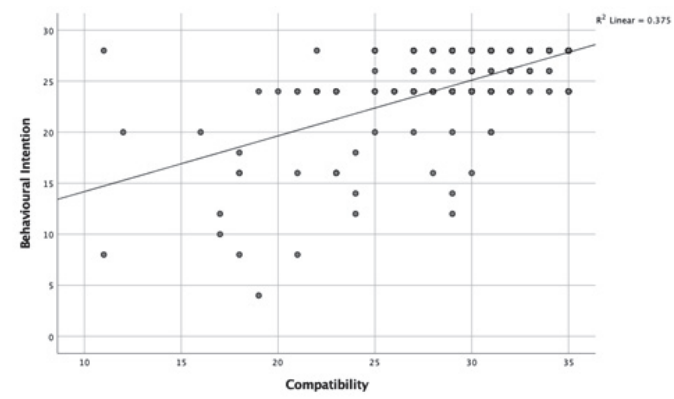

FIGURE 7

SCATTERPLOT OF THE RELATIONSHIP BETWEEN BEHAVIOURAL INTENTION AND PERCEIVED RISK

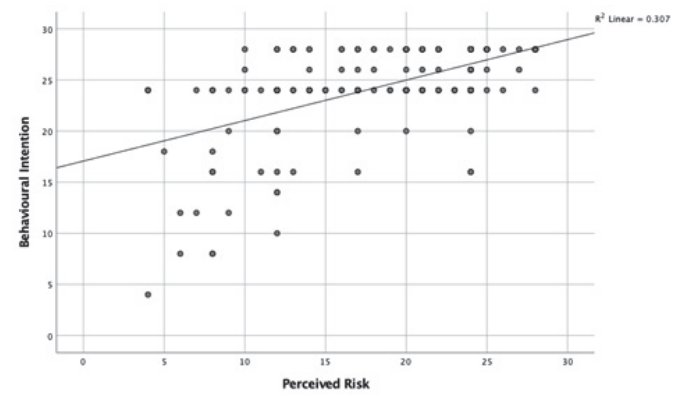


FIGURE 8

SCATTERPLOT OF THE RELATIONSHIP BETWEEN BEHAVIOURAL INTENTION AND PERCEIVED TRUST

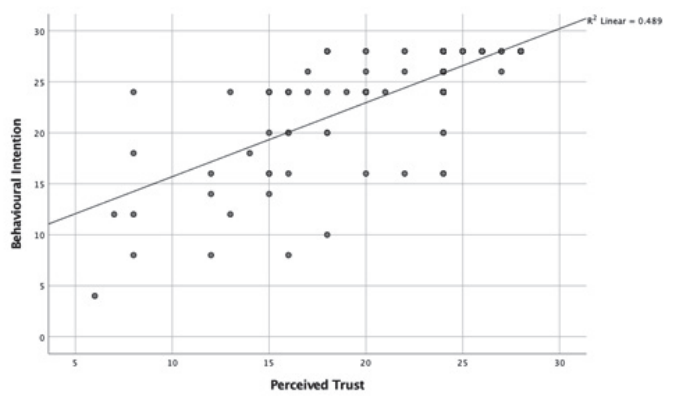

FIGURE 9

SCATTERPLOT OF THE RELATIONSHIP BETWEEN BEHAVIOURAL INTENTION AND SELF-EFFICACY

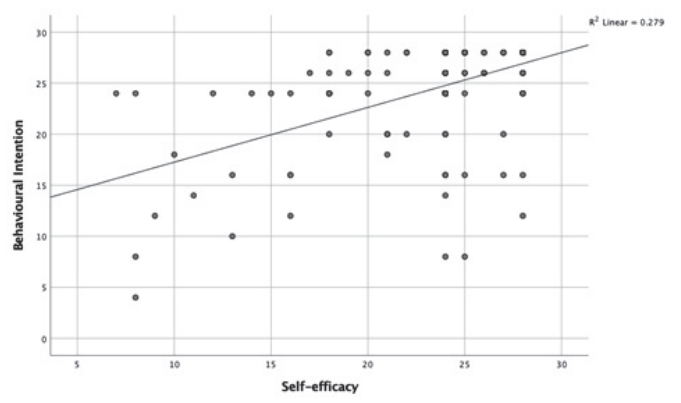

An analysis of the relationship between behavioural intention and its strength of association with the two sub-constructs: perceived ease of use, and perceived usefulness from the Technological Acceptance Model was undertaken through a correlation analysis. In addition, an analysis of the strength of relationship between behavioural intention and the four Innovation Diffusion Theory constructs: compatibility, self-efficacy, perceived risk, and perceived trust was undertaken. The results indicating strong positive associations between all five sub-constructs and overall behavioural intention. The results of which are presented in Table 6. 
TABLE 6

PEARSON PRODUCT MOMENT CORRELATION MAGNITUDES FOR BEHAVIOURAL INTENTION AGAINST TAM AND IDT CONSTRUCTS

\begin{tabular}{l|lllllll} 
& $\begin{array}{l}\text { Behavioural } \\
\text { Intention }\end{array}$ & $\begin{array}{l}\text { Perceived } \\
\text { Ease Of } \\
\text { Use }\end{array}$ & Compatibility & $\begin{array}{l}\text { Perceived } \\
\text { Usefulness }\end{array}$ & $\begin{array}{l}\text { Perceived } \\
\text { Risk }\end{array}$ & $\begin{array}{l}\text { Perceived } \\
\text { Trust }\end{array}$ & $\begin{array}{l}\text { Self- } \\
\text { efficacy }\end{array}$ \\
\hline $\begin{array}{l}\text { Behavioural } \\
\text { Intention }\end{array}$ & 1 & & & & & \\
$\begin{array}{l}\text { Perceived } \\
\text { Ease Of Use } \\
\text { Compatibility }\end{array}$ & $.561^{* *}$ & 1 & & & & \\
$\begin{array}{l}\text { Perceived } \\
\text { Usefulness }\end{array}$ & $.613^{* *}$ & $.605^{* *}$ & 1 & & & \\
$\begin{array}{l}\text { Perceived } \\
\text { Risk }\end{array}$ & $.632^{* *}$ & $.636^{* *}$ & $.626^{* *}$ & 1 & & \\
$\begin{array}{l}\text { Perceived } \\
\text { Trust }\end{array}$ & $.554^{* *}$ & $.408^{* *}$ & $.436^{* *}$ & $.430^{* *}$ & 1 & \\
\multicolumn{1}{c}{ Self-efficacy } & $.699^{* *}$ & $.528^{* *}$ & $.540^{* *}$ & $.566^{* *}$ & $.716^{* *}$ & 1 & \\
\hline
\end{tabular}

**. Correlation is significant at the 0.01 level (2-tailed).

A hierarchical multiple linear regression analysis was undertaken to predict behavioural intention based on the six constructs that compose the Technological Acceptance Model and the Innovation Diffusion Theory, namely: perceived ease of use, perceived usefulness, compatibility, perceived risk, perceived trust and respondent's self-efficacy; controlling for the variance attributable to gender, age and highest level of education. The results of the hierarchical multiple linear regression are presented in Table 7. There was independence of residuals, as assessed by a Durbin-Watson statistic of 2.185. There was evidence of heteroscedasticity, as assessed by visual inspection of a plot of studentized residuals versus unstandardized predicted values. There was no evidence of multicollinearity, as assessed by tolerance values greater than 0.1 . There was a single studentized deleted residual greater than +3 standard deviations, measuring 3.27. There were 2 leverage values greater than 0.2 measuring .22 and .21. However, there were no influential observations as assessed with all Cook's distances being below 1.0. The full model to predict behavioural intention (model 2) was statistically significant, $\mathrm{R}^{2}=.622, \mathrm{~F}(11$, $220)=30.19, \mathrm{p}<.0005$; adjusted $\mathrm{R}^{2}=.602$. The addition of the six Technological Acceptance Model and the Innovation Diffusion Theory constructs to the prediction of behavioural intention led to a statistically significant increase in $\mathrm{R}^{2}=.547, \mathrm{~F}(6,220)=53.10, \mathrm{p}<.0005$. The only predictor variables that statistically significantly predicted behavioural intention are the single Technological Acceptance Model construct perceived usefulness $(\mathrm{t}=3.12, \mathrm{p}<.0005)$ and the two Innovation Diffusion Theory constructs compatibility $(\mathrm{t}=2.84, \mathrm{p}<.01)$ and perceived trust $(\mathrm{t}=5.38, \mathrm{p}<.0001)$. All three constructs having an increasing effect on behavioural intention levels, as is evident by their respective standardised beta coefficients of $0.20,0.18$, and 0.38 respectively. 
TABLE 7

PREDICTORS OF BEHAVIOURAL INTENTION

\begin{tabular}{|c|c|c|c|c|c|c|c|c|c|c|}
\hline \multirow[b]{2}{*}{ Variables } & \multicolumn{5}{|c|}{ Model 1} & \multicolumn{5}{|c|}{ Model 2} \\
\hline & B & SE & $\boldsymbol{\beta}$ & $\mathbf{t}$ & Sig. & B & SE & $\boldsymbol{\beta}$ & $\mathbf{t}$ & Sig. \\
\hline (Constant) & 24.80 & 1.05 & & 23.58 & 0.000 & 2.43 & 1.58 & & 1.54 & 0.125 \\
\hline Gender & -0.97 & 0.57 & -0.11 & -1.69 & 0.092 & -0.47 & 0.39 & -0.06 & -1.20 & 0.231 \\
\hline Age_Dummy1 & 2.07 & 0.97 & 0.18 & 2.14 & 0.033 & 0.51 & 0.65 & 0.04 & 0.78 & 0.436 \\
\hline Age_Dummy2 & 1.31 & 0.81 & 0.14 & 1.62 & 0.107 & 0.02 & 0.54 & 0.00 & 0.04 & 0.968 \\
\hline Age_Dummy3 & 1.32 & 0.79 & 0.15 & 1.68 & 0.095 & 0.58 & 0.51 & 0.07 & 1.14 & 0.257 \\
\hline EducationDummy1 & -2.37 & 1.04 & -0.16 & -2.28 & 0.024 & -0.94 & 0.68 & -0.06 & -1.37 & 0.172 \\
\hline EducationDummy2 & 0.68 & 0.59 & 0.08 & 1.16 & 0.249 & 0.53 & 0.39 & 0.06 & 1.37 & 0.172 \\
\hline $\begin{array}{l}\text { Perceived Ease of } \\
\text { Use }\end{array}$ & & & & & & 0.10 & 0.08 & 0.08 & 1.31 & 0.193 \\
\hline $\begin{array}{l}\text { Perceived } \\
\text { Usefulness }\end{array}$ & & & & & & 0.21 & 0.07 & 0.20 & 3.12 & 0.002 \\
\hline Compatibility & & & & & & 0.16 & 0.06 & 0.18 & 2.84 & 0.005 \\
\hline Perceived Risk & & & & & & 0.05 & 0.04 & 0.07 & 1.20 & 0.232 \\
\hline Perceived Trust & & & & & & 0.40 & 0.07 & 0.38 & 5.38 & 0.000 \\
\hline Self-Efficacy & & & & & & 0.01 & 0.06 & 0.01 & 0.12 & 0.907 \\
\hline $\mathrm{R}^{2}$ & 0.08 & & & & & 0.62 & & & & \\
\hline $\mathrm{F}$ & 3.05 & & & & 0.007 & 30.19 & & & & 0.000 \\
\hline$\Delta \mathrm{R}^{2}$ & & & & & & 0.55 & & & & \\
\hline$\Delta \mathrm{F}$ & & & & & & 53.10 & & & & 0.000 \\
\hline
\end{tabular}

The base predictive power from block 1 control variables gender, age and highest level of education produced a baseline $\mathrm{R}^{2}=.075, \mathrm{~F}(6,226)=3.052, \mathrm{p}<.007$. The only statistically significant control variables being the dichotomous dummy classification of age, indicating statistically significant greater average behavioural intention levels for those participants aged between 20 and 30 years $(\mathrm{M}=25.49$, SD $=3.86)$ compared to those that are not $(\mathrm{M}=24.59, \mathrm{SD}=4.23) \mathrm{t}=2.14, \mathrm{p}<.05$. In addition to, the dichotomous classification of education, indicating statistically significant lower average behavioural intention levels for those participants with a Leaving Certificate $(\mathrm{M}=21.00, \mathrm{SD}=5.88)$ compared to those whose highest level of education is greater than a Leaving Certificate $(\mathrm{M}=25.00, \mathrm{SD}=3.93) \mathrm{t}=$ $2.28, \mathrm{p}<.05$.

A bootstrap simulation was undertaken with 1000 iterations. The bootstrap was based on a stratified random sampling strategy with the demographic variables gender, age, and highest level of education defining the strata. The results of the bootstrap simulation are presented in Table 8 . The results indicating bias scores predominately within three tenths of the original multiple hierarchical regression findings. 
TABLE 8

RESULTS OF BOOTSTRAP SIMULATION ( $=1000)$

\begin{tabular}{|c|c|c|c|c|c|c|c|c|}
\hline \multirow[b]{2}{*}{ Variables } & \multicolumn{4}{|c|}{ Model 1} & \multicolumn{4}{|c|}{ Model 2} \\
\hline & B & Bias & SE & Sig & B & Bias & SE & Sig. \\
\hline (Constant) & 24.80 & -0.01 & 0.92 & 0.001 & 2.43 & -0.50 & 2.90 & 0.441 \\
\hline Gender & -0.97 & 0.01 & 0.51 & 0.069 & -0.47 & 0.01 & 0.34 & 0.194 \\
\hline Age_Dummy1 & 2.07 & 0.00 & 0.76 & 0.006 & 0.51 & -0.08 & 0.66 & 0.446 \\
\hline Age_Dummy2 & 1.31 & 0.01 & 0.78 & 0.097 & 0.02 & -0.01 & 0.48 & 0.957 \\
\hline Age_Dummy3 & 1.32 & 0.03 & 0.60 & 0.031 & 0.58 & -0.04 & 0.47 & 0.243 \\
\hline Education Dummy1 & -2.37 & -0.03 & 0.97 & 0.017 & -0.93 & 0.05 & 0.62 & 0.163 \\
\hline Education Dummy2 & 0.68 & -0.01 & 0.58 & 0.264 & 0.53 & -0.03 & 0.38 & 0.198 \\
\hline Perceived Ease of Use & & & & & 0.10 & 0.02 & 0.12 & 0.421 \\
\hline Perceived Usefulness & & & & & 0.21 & 0.04 & 0.11 & 0.085 \\
\hline Compatibility & & & & & 0.16 & 0.00 & 0.07 & 0.039 \\
\hline Perceived Risk & & & & & 0.05 & 0.00 & 0.04 & 0.239 \\
\hline Perceived Trust & & & & & 0.40 & -0.03 & 0.10 & 0.002 \\
\hline Self-Efficacy & & & & & 0.01 & -0.01 & 0.10 & 0.944 \\
\hline
\end{tabular}

a. Unless otherwise noted, bootstrap results are based on 1000 stratified bootstrap samples

\section{DISCUSSION}

The aim of this research study was to explore and test a conceptual model that explained consumers' behavioural intention to adopt mobile banking in Ireland. By identifying the important factors contained in TAM and IDM through the literature a conceptual model was developed that extended TAM and IDM to include perceived risk, perceived trust and self-efficacy. This extended model explained $62 \%$ of the variance in consumer behavioural intention to adopt mobile banking in Ireland. This compares favourably with the explanatory power of TAM which is $\mathrm{R}=35-40 \%$ as found by Venkatesh and Davis (2000).

Perceived usefulness, compatibility and perceived trust have featured in previous research into technology acceptance (Laukkanen, 2007; Kim et al., 2009; Lin, 2011; Ha et al. 2012; Al-Jabri \& Sohil, 2012; Lee et al., 2013; Dash \& Bhusan, 2014; Nel \& Boshoff, 2014; Talukder et al. 2014; Ramlugun \& Issuree, 2014; Shaikh \& Karjaluoto, 2014; Yu et al. 2015; Koksal, 2016; Alalwan et al., 2016) and the findings here, in part, are consistent with the findings of those studies. In particular, this research identifies perceived trust as having the most positive effect on a consumers' behavioural intentions to adopt mobile banking, followed by perceived usefulness and compatibility. The findings suggest that the effect of perceived trust on behavioural intention is approximately twice as large as the effect of perceived usefulness and compatibility.

The research literature suggests that perceived ease of use and self-efficacy would also have a significant positive effect on behavioural intention to adopt mobile banking. However, these claims were not supported from these results. The results suggest that self-efficacy has no impact on behavioural intention to adopt mobile, although the effect was not statistically significant. Additionally, the study argued that perceived risk was expected to have a significant negative effect on behavioural intention of consumers to adopt mobile banking, this was not supported by the results.

The study found perceived trust $(\mathrm{B}=.40, \mathrm{p}<.0001)$ to have a significant positive effect on behavioural intention towards mobile banking adoption in Ireland which is consistent with findings in 
previous studies (Kim et al., 2009; Nel \& Boshoff, 2014; Koksal, 2016). This finding supports the argument that if mobile banking is perceived as trustworthy it is more likely to be adopted. Results obtained reinforced the findings of previous studies (Talukder et al. 2014; Koksal, 2016) with respect to this construct and in particular indicated a significant relationship between perceived trust and intention to adopt mobile banking. As expected, privacy and security were seen as important dimensions in banking services and mobile banking is expected to deliver these.

Perceived usefulness $(\mathrm{B}=.21, \mathrm{p}<.002)$ was shown to have a significant positive relationship with behavioural intention to adopt mobile banking. This finding is consistent with previous research (Laukkanen, 2007; Lee et al., 2013; Ha et al., 2012; Talukder et al. 2014; Ramlugun \& Issuree, 2014; Shaikh \& Karjaluoto, 2014; Yu et al. 2015; Koksal, 2016; Alalwan et al., 2016). Mobile banking was perceived to be useful by consumers in this study, in the survey $96.67 \%$ of respondents agreed to some degree with the statement that "Mobile banking is useful". Results indicate that mobile banking characteristics such as ubiquity, immediacy and ability to conduct transactions or access information anytime, anywhere strengthens this perception. This leads to consumers developing a positive behavioural intention to its adoption as found by Laukkanen, 2007; Lee et al., 2013; Ha et al., 2012; Shaikh \& Karjaluoto, 2014; Talukder et al. 2014; Yu et al. 2015; Koksal, 2016; Alalwan et al., 2016; Ramlugun \& Issuree, 2014.

Results further suggest that compatibility $(\mathrm{B}=.16, \mathrm{p}=.005)$ had a significant positive effect on behavioural intention to adopt mobile banking in Ireland. These findings concur with other research studies (Kim et al., 2009; Lin, 2011; Ha et al. 2012; Al-Jabri \& Sohil, 2012; Dash \& Bhusan, 2014); that found compatibility to have a significant impact as a determinant for prediction of mobile banking adoption. These findings point to the importance of the respondent's assessment of the extent to which mobile banking is compatible with their lifestyle and their familiarity with the technologies that enable it. These results indicate that if mobile banking is perceived to be consistent with lifestyles, experience and values of individuals, there is a higher likelihood of adoption of mobile banking.

Perceived ease of use, which Davis' (1989) TAM asserts to be one of the two most important factors in technology acceptance behaviour and the best predictors of future use was not supported in these research findings. The research found perceived ease of use $(B=.10, p=.193)$ not to be a significant factor in determining behavioural intention to adopt mobile banking in Ireland. This contradicts previous findings of studies into mobile banking acceptance (Talukder et al. 2014; Shaikh \& Karjaluoto, 2014; Ramlugun \& Issuree, 2014; Yu et al. 2015; Koksal, 2016; Alalwan et al., 2016). This might be explained by the fact that $92.9 \%$ of respondents in this study agreed to some degree with the statement that "Mobile banking is easy to use" in the survey instrument. This may be a reflection that respondents were well informed and familiar in the use of mobile technology applications and electronic banking services.

Self-efficacy, which relates to the concept that when a consumer has the ability to perform a task (skills required to use an innovation) there is a greater chance that they will accept and adopt the innovation in their everyday lives (Ramlugun \& Issuree, 2014; Koksal, 2016; Alalwan et al., 2016). This research study found self-efficacy $(B=.01, p=.907)$ not to have a statistically significant influence on behavioural intention to adopt mobile banking in Ireland. Although the result was insignificant, the result would seem to suggest that there is no association between self-efficacy and behavioural intention. This finding is contrary to previous findings (Ramlugun \& Issuree, 2014; Koksal, 2016; Alalwan et al., 2016), who found that there was a positive relationship between perceived self-efficacy and intention to adopt mobile banking. Potential reasons of explanation in the research results may be found in the high proportion of respondents that perceived mobile banking as easy to use and therefore perceive themselves as having the ability to perform mobile banking successfully. This result may indicate higher levels of experience with mobile applications or comfort with the use of mobile banking by respondents.

Finally, with respect to perceived risk $(\mathrm{B}=-.010, \mathrm{p}=.865)$, which Ram and Seth (1989) argue can cause potential adopters of new innovations to be wary of the innovation and in particular refers to the degree of risk in using innovations, is found not to be a statistically significant factor in the relationship of behavioural intention to adopt mobile banking in Ireland. These findings also contradict previous findings in the research into mobile banking adoption (Luarn \& Lin, 2005; Al-Jabri \& Sohil, 2012; Ha et al. 2012) 
who found perceived risk to be a significant factor influencing behavioural intention to adopt mobile banking. Possible explanations for this divergence may be found in the study. Only $14.6 \%$ of respondents either disagreed with or were undecided about the statement "Overall, I trust mobile banking" from the survey instrument which indicates that perceived risk is not perceived as a barrier to adoption in an Irish context. Both the perceived risk and perceived trust constructs were also highly correlated $(\mathrm{r}=.716, \mathrm{p}<$ 0.01). This indicates that the vast majority of respondents in the study would seem to be aware of perceived risks, understand them and that the related uncertainty they represent was reduced for them to a level that they found acceptable. Additionally, only $31.63 \%$ of respondents did not perceive mobile banking as safe to some degree.

\section{LIMITATIONS AND FUTURE RESEARCH}

The research findings raised a number of areas of interest which could be examined in more detail through qualitative research as a method to gain a deeper understanding of the role of the various constructs within the model and consumers' behavioural intentions. The constructs of perceived trust, perceived usefulness and compatibility were found to have a significant positive relationship with consumers' behavioural intentions to use mobile banking. Although, the lack of influence of perceived risk, perceived ease of use, and self-efficacy would seem to contradict the literature. A deeper understanding of consumer understanding of these concepts and the strength of their influence would be beneficial. More qualitative or mixed method research studies should be undertaken to analyse consumer behavioural intention towards mobile banking.

The use of snowball sampling, although accepted as a technique for gathering evidence when the underlying population characteristics are unknown, it is well recognised that its relative non-probabilistic characteristic limits its use as an inferential technique to the general population under consideration. The researchers attempt to overcome these limitations through the use of bootstrap sampling, were the sample was considered to represent the population and random sampling was undertaken in order to build an empirical picture of the underlying sampling distribution. Future work should concentrate on randomised participant selection.

A limitation of the research study is that it concentrated on six factors affecting behavioural intention to adopt mobile banking. The proposed model has an explanatory power of $62 \%$. In doing this the research may have overlooked additional import constructs such as social influence whose inclusion may have increased the model's explanatory power. Another limitation relates to the survey and sample techniques employed in the research study. The most significant limitation of the research only measures behavioural intention to adopt mobile banking and not actual adoption behaviour.

Finally, the interacting relationship between the two TAM constructs and the four IDT, as measured through their respective correlations with each other; would seem to suggest a large proportion of shared variance. Future studies should attempt to remove this shared variance and test the underlying residual construct's influence of behavioural intention to adopt mobile banking.

\section{CONCLUSION}

The aim of this research was to explore and propose a conceptual model that explained consumer behavioural intention to adopt mobile banking in Ireland. The research results indicated that the conceptual model developed enabled the researchers to explain $62 \%$ of the variance in consumers' behavioural intentions to adopt mobile banking in Ireland. These findings have a higher than explanatory power in comparison to previous TAM research which accounted for between $35 \%$ and $40 \%$ of the variance in consumer behavioural intention, as found in Venkatesh and Davis (2000).

The conceptual model developed in this study included the measures of the relationship between perceived usefulness, perceived ease of use, compatibility, perceived risk, perceived trust, self-efficacy and consumers' behavioural intentions to adopt mobile banking. The findings indicate that perceived 
trust, perceived usefulness and compatibility were the most significant factors that influence consumers' behavioural intentions to use mobile banking.

The findings of this research study also indicate that mobile banking adoption rates are likely to increase if they are compatible with consumers' experiences, lifestyle, beliefs and fulfil their expectations. This study illustrates the importance placed on compatibility of new technologies and services by consumers. Banks must strive to develop and deliver mobile banking services that are compatible with existing technologies which consumers are familiar with. The study found that if consumers view mobile banking as compatible with their beliefs, values, lifestyle and experiences there is a higher probability that they will adopt mobile banking.

\section{REFERENCES}

Agarwal, R., \& Prasad, J. (1998). The antecedents and consequents of user perceptions in information technology adoption. Decision Support Systems, 22(1), 15-29.

Al-Jabri, I.M., \& Sohail, M.S. (2012). Mobile Banking Adoption: Application of Diffusion of Innovation theory. Journal of Electronic Commerce Research, 13(4), 379-391.

Alalwan, A.A., Dwivedi, Y.K., Rana, N.P.P., \& Williams, M.D. (2016). Consumer adoption of mobile banking in Jordan. Journal of Enterprise Information Management, 29(1), 118-139.

Backbase. (2017). Banking 2025 Whitepaper, Four Pillars of the Digital First Bank. Retrieved July 12, 2019, from https://www.backbase.com/resources/banking-2025-whitepaper

Banking \& Payments Federation Ireland. (2018) 'Online and Mobile Banking Report'. [Online]. Retrieved July 12, 2019, from https://www.bpfi.ie/wp-content/uploads/2019/05/BPFI-PaymentsMonitor-H2-2018-FINAL-for-website.pdf

Bitner, M.J., Brown, S.W., \& Meuter, M.L. (2000). Technology infusion in service Encounters. Journal of the Academy of marketing Science, 8(1), 138-149.

Cheung, M.C., \& Chang, C. (2001). Perceptual Factors Underlying User Preferences toward Product Form of Mobile Phones. Industrial Ergonomics, 27(4), 247-258.

Dash, M., \& Bhusan, P.B. (2014). Determinants of Customers' Adoption of Mobile Banking: An Empirical Study by Integrating Diffusion of Innovation with Attitude. Journal of Internet Banking and Commerce, 19(3), 1-21.

Davis, F.D. (1989). Perceived Usefulness, Perceived Ease of Use, and User Acceptance of Information Technology. MIS Quarterly, 13(3), 319-340.

Ernst \& Young. (2017). Global consumer banking survey. [Online]. Retrieved July 15, 2019, from https://eyfinancialservicesthoughtgallery.ie/global-consumer-banking-survey/

Garcia, R., Bardhi, F., \& Friedrich, C. (2007). Overcoming consumer resistance to innovation. MIT Sloan Management Review, 48(4), 82.

Gourville, J.T. (2006). Eager sellers \& stony buyers. Harvard Business Review, 84(6), 98-106.

Gu, J.C., Lee, S.C., \& Suh, Y.H. (2009). Determinants of behavioral intention to mobile banking. Expert Systems with Applications, 36(9), 11605-11616.

Gurtner, S., Reinhardt, R., \& Soyez, K. (2014). Designing mobile business applications for different age groups. Technological Forecasting and Social Change, 88, 177-188.

Ha, K., Canedoli, A., Baur, A.W., \& Bick, M. (2012). Mobile banking - insights on its increasing relevance and most common drivers of adoption. Electronic Markets, 22(4), 217-227.

Heidenreich, S., \& Handrich, M. (2015). What about passive innovation resistance? Investigating adoption-related behavior from a resistance perspective. Journal of Product Innovation Management, 32(6), 878-903.

Illia, A., Ngniatedema, T., \& Huang, Z. (2015). A Conceptual Model for Mobile Banking Adoption. Journal of Management Information and Decision Sciences, 18(1), 111-122.

Kim, G., Shin, B., \& Lee, H.G. (2009). Understanding dynamics between initial trust and usage intentions of mobile banking. Information Systems Journal, 19(3), 283-311. 
Kim, K.K., Prabhakar, B., \& Park, S.K. (2009). Trust, perceived risk, and trusting behaviour in internet banking. Asia Pacific Journal of Information Systems, 19(3), 1-23.

Koksal, M.H. (2016). The intentions of Lebanese consumers to adopt mobile banking. International Journal of Bank Marketing, 34(3), 327-346.

Kuisma, T., Laukkanen, T., \& Hiltunen, M. (2007). Mapping the reasons for resistance to Internet banking: A means-end approach. International Journal of Information Management, 27(2), 7585.

Laukkanen, T. (2007). Internet vs mobile banking: comparing customer value perceptions. Business Process Management Journal, 13(6), 788-797.

Laukkanen, T. (2016). Consumer adoption versus rejection decisions in seemingly similar service innovations: The case of the Internet and mobile banking. Journal of Business Research, 69(7), 2432-2439.

Laukkanen, T., \& Kiviniemi, V. (2010). The role of information in mobile banking Resistance. International Journal of Bank Marketing, 28(5), 372-388.

Lee, H., Zhang, Y., \& Chen, K.L. (2013). An investigation of features and security in mobile banking strategy. Journal of International Technology and Information Management, 22(4), 23.

Lee, M.C. (2009). Factors influencing the adoption of internet banking: An integration of TAM and TPB with perceived risk and perceived benefit. Electronic Commerce Research and Applications, 8(3), 130-141.

Lee, Y., Hsieh, Y., \& Hsu, C. (2011). Adding Innovation Diffusion Theory to the Technology Acceptance Model: Supporting Employees' Intentions to use E-Learning Systems. Journal of Educational Technology \& Society, 14(4), 124-137.

Luarn, P., \& Lin, H.H. (2005). Toward an understanding of the behavioral intention to use mobile banking. Computers in Human Behaviour, 21(6), 873-891.

Malaquias, R.F., \& Hwang, Y. (2016). An empirical study on trust in mobile banking: A developing country perspective. Computers in Human Behavior, 54, 453-461.

Moser, F. (2014). Mobile Banking: A fashionable concept or an institutionalized channel in future retail banking? Analysing patterns in practical and academic mobile banking literature. International Journal of Bank Marketing, 33(2), 162-177.

Muñiz, A.M., \& Schau, H.J. (2011). How to inspire value-laden collaborative consumer generated content. Business Horizons, 54(3), 209-217.

Nel, J., \& Boshoff, C. (2014). The impact of cross-channel cognitive evaluations on the continued use intentions of mobile banking. Management Dynamics, 23(4), 2.

Phuangthon, D., \& Malisawan, D. (2005). A study of behavioral intention for $3 G$ mobile internet technology: preliminary research on mobile learning. Proceedings of the Second International Conference on eLearning for Knowledge-Based Society, August, Bangkok.

PwC's. (2018). Digital Banking Consumer Survey: Mobile users set the agenda. Retrieved July 15, 2019, from https://www.pwc.com/il/he/bankim/assets/2018/PwC\%202018\%20Digital\%20Banking\%20Cons umer\%20Survey.pdf

Raida, R.E., \& Néji, B. (2013). The Adoption of the E-Banking: Validation of the Technology Acceptance Model. Technology and Investment, 4, 197-203.

Ram, S., \& Sheth, J.N. (1989). Consumer Resistance to Innovations: The Marketing Problem and its solutions. Journal of Consumer Marketing, 6(2), 5-14.

Ramlugun, V. G., \& Issuree, H. (2014). Factors Determining Mobile Banking Adoption in Mauritius. International Journal of Innovative Research and Development, 3(1), 193-201.

Rodgers, E.M. (2003). Diffusion of innovations, 5th Ed. New York: The Free Press.

Salahuddin, A.B., Chowdhury, I.A., Mahtab, H., \& Khabir, M.L. (2017). Factors Influencing the Mobile Banking Adoption in the Banking Sector of Bangladesh. Australasian Journal of Business, Social Science and Information Technology, 3(3), July. 
Shaikh, A.A., \& Karjaluoto, H. (2015). Mobile Banking Adoption: A Literature Review. Telematics and Informatics, 32, 129-142.

Shamsul, A.M., Hamidon, K., \& Imdadullah, H. (2017). Mobile Banking Adoption: The Impacts of Social Influence, Ubiquitous Finance Control and Perceived Trust on Customers' Loyalty. Science International (Lahore), 29(4), 829-836.

Talukder, M., Quazi, A., \& Sathye, M. (2014). Mobile Phone Banking Usage Behaviour: An Australian Perspective. Australasian Accounting, Business and Finance Journal, 8(4), 83-104.

Tung, F.C., Yu, T.W., \& Yu, J.L. (2014). An Extension of Financial Cost, Information Quality and IDT for Exploring Consumer Behavioral Intentions to Use the Internet Banking. International Review of Management and Business Research, 3(2), 1229.

Vargo, S.L., \& Lusch, R.F. (2008). Service-dominant logic: continuing the evolution. Journal of the Academy of marketing Science, 36(1), 1-10.

Venkatesh, V., \& Davis, F. D. (2000). A Theoretical Extension of the Technology Acceptance Model: Four Longitudinal Field Studies. Management Science, 46(2), 186-204.

Wafi, A., \& Imdadullah, H.R. (2016). The Impacts of M-Commerce on Saudi Banks. Journal of Management and Strategy, 7(2), 1-8.

Walid, C., \& Kamel, E.H. (2019). International Journal of Bank Marketing, 37(1), 69-96.

Yang, M., \& Park, K.H. (2011). Self-service technologies (SSTs): determinants of adoption and its postusage outcomes from a focal company perspective. International Journal of Services and Operations Management, 8(3), 305-321.

Yu, C., Li, C., \& Chantatub, W. (2015). Analysis of Consumer E-Lifestyles and Their Effects on Consumer Resistance to Using Mobile Banking: Empirical Surveys in Thailand and Taiwan. International Journal of Business and Information, 10(2), 198.

Yu, C.S., \& Chantatub, W. (2016). Consumers' Resistance to Using Mobile Banking: Evidence from Thailand and Taiwan. International Journal of Electronic Commerce Studies, 7(1), 21. 